\title{
NOBLE POET DERDEMEND: THE ORSK PERIOD OF LIFE, NEW FACTS AND THOUGHTS (ON THE $160^{\mathrm{TH}}$ ANNIVERSARY OF HIS BIRTH)
}

\author{
Fauziya Aukhadievna Bayramova, \\ Union of Tatarstan Writers, \\ 14 Mushtari Str., Kazan, 420015, Russian Federation, \\ ittifak@yandex.ru.
}

\begin{abstract}
This article is devoted to Derdemend (Zakir Ramiev), an outstanding poet of the Tatar people, a patriot, an owner of gold mines and the Orsk period of his life. Despite the fact that the poet's biography, based on scientific research, has become part of the theory of Tatar literature, his Orsk period has been recently supplemented by new facts, discovered by F. Karimi, R. Fakhreddin, M. Gainullin, M. Rakhimkulov, L. Khamidullin, and T. G. Cherkas, who studied the Orsk region. Certain issues have been updated. It is emphasized that Z. Ramiev's adolescence and youth passed in the city of Orsk where he became a multifaceted and noble personality. Derdemend, known as a talented and original poet in the Tatar world and the one who played an important role in the gold mining industry of Russia, exerted noticeable influence on the cultural and political life of the Orsk region. After the October Revolution of 1917, the connection between the last years of the poet's life and the city of Orsk became even more apparent.
\end{abstract}

Key words: Tatar poetry, poet, gold miner, biography, city of Orsk, Derdemend.

In recent years, theory of literature often turns to the biography genre to explore the significance of creative personalities on a global scale, or their role in the culture and history of their people's literature, social and political life. A biography implies "a literary or scientific explanation of the history of personal life, aimed at finding and identifying the roots of socially significant political activities in an individual biographical experience of a person" [Sobolevskaia, p. 90]. Derdemend's (Zakir Ramiev, 1859-1921) poetry occupies its own place in the history of the Tatars, not only due to its literary and aesthetic features, but also its social status. The history of the studies, devoted to the poet's oeuvre, is quite rich, as his works updated Tatar poetry, based on its centuries-old traditions, raising it to the world level. In Derdemend's poetry, literary scholars find the embodiment of literary, aesthetic and philosophical concepts, and systems characteristic of Eastern and Arab cultures [Khalit, 1986], [Khisamov, 1989], [Zagidullina, 2006], [Saiapova, 2014], [Saiapova, 1997], [Khabutdinova, 2005], [Khabutdinova, 2006], [Friderikh, 2014], [Gilazov, 2014], et al. On the whole, Derdemend's scientifically based biography has been compiled in Tatar literary criticism; however, it is necessary to complement some periods of his life with new facts, highlighting the events not known before in order to understand his assessment of certain facts. This article studies the Orsk period of the poet's life from a new angle.

The Orsk region occupies a special place in Derdemend's rich and complex life. Various stages of the poet's life are associated with this city. Here, the facts from his personal life are intertwined with the events that ensured the social development and the spiritual and cultural renewal of the Tatar people. In scientific works, the Orsk period is associated only with the last years of his life and death; however, the poet's adolescence and youth passed in this city! Unfortunately, Derdemend's biography has not been compiled in a chronological order, therefore, to complement it, we use various sources. As you know, Derdemend was born in 1859, in the village of Zhirgan, located in the Southern Urals. At the age of three, he and his family moved to the village of Yulyk. The future poet Derdemend - Muhammadzakir Ramiev, together with his elder brother, first went to primary school in the village of Yulyk, then they continued their studies in Orsk.

"When they were growing up in Yulyk, there was only an elementary school," writes L. Khamidullin. "After that, they studied for two winters in the city of Orsk" [Dərdemənd, 2003, p. 75, p. 94]. The article does not describe the brothers' studies in Orsk. According to logic, this period dates back to the early 1870s, the adolescents were 12-13 years old at that time. 
Fragmentary facts about this period are given in Rizaeddin Fakhreddin's work: "Shakir efende, having received primary education in the village of Yulyk, continued his studies at the Damella Garif Megazi madrasah, later, he studied with Gabdulla Bine Saed in the village of Mullakay on the banks of the Sakmar River. In 1874, he completed his studies" [Fakhreddin, 2010, pp. 422-423]. Accordingly, Zakir and Shakir Ramievs went to the Damella Garif Megazi madrasah in Orsk.

L. Khamidullin, who thoroughly studied the life and literary and cultural activities of the Tatar intellectuals from the Orenburg-Orsk region, complemented these data with new facts from the Ramiev generation activities. He wrote about the Orsk period of Derdemend's life: “After graduating from the Mullakay madrasah, the Ramievs moved to Orsk again to continue their studies. Zakir left for Turkey, and after living in Istanbul for about two years, he came back in 1881" [Dordemənd, 2003, p. 94]. As you can see, after graduating from the Mullakay madrasah in 1874, the Ramiev brothers lived and studied in Orsk from 1875 to 1880 . Zakir, who was $16-20$ years old at that time, spent his youth in Orsk, and as his Istanbul period was short, we can conclude that his personality was shaped here.

When Derdemend first saw Orsk, there was a mosque and madrassas, more than 2000 Muslims lived in the city. There were also Russian churches, Russian schools and gymnasiums, a post office, a hospital, a court, as well as police, customs and military institutions. Wealthy Tatars held the main city capital in their hands. When gold was found in the neighboring steppes, they became the owners of those mines and traded gold with the world. In our opinion, Z. Ramiev's decision to leave for Turkey was influenced by those rich Tatars who helped him to solve money problems.

Note, in 1881, after returning from Turkey, Derdemend lived in Orsk, not in the village of Yulyk, the Ramievs had their own house in this city. It is known that Sh. Ramiev lived here with his family until 1900. This fact is confirmed both by the notes of R. Fakhreddin and by those who studied the history of this region: "At the end of the $19^{\text {th }}$ century, in Orsk, there lived the family of Ramievs, gold miners - they owned mines in the Orsk district" [Cherkas, 2003]. L. Khamidullin mentions the following important event in the Orsk period of Zakir's life: "Having returned from abroad, Zakir lived in Orsk for some time. He was engaged in trade, and spent summer months on gold mines. In the second year after returning from
Turkey, he married Makhubjamal, the daughter of the big Orsk merchant Burnaev Mustafa Musyvich (1861-1943)" [Dordemənd, 2003, p. 95].

In the books, published by the famous Orenburg enlightener Madina Rakhimkulova, it is written that Makhubjamal was born in 1864 and was originally from Tatar Kargaly [Ramievs, 1999, p. 27]. The poet's marriage is described in the memoirs of Derdmend's sister-in-law Asma Rakhmatullina-Ibragimova: "(brother-in-law) took my sister, abystay, when she was 16 years old. He married her very young, he taught her and educated her " [ Ramievlar, 1999, p. 180-181].

In Orsk, Derdemend's father-in-law, Mustafa Burnaev, was one of the richest men who kept expanding his trade in the region, and half of the city was made up of his relatives. Of course, he married off his daughter to the son of the gold mines owner, Muhammadsadyk Ramiev, who possessed great wealth, money. According to L. Khamidullin, he bought his first gold mine in 1869, afterwards, "sparing neither strength nor money", he annually acquired several gold "centers": "According to historical documentary records, throughout his life, M. Ramiev owned more than 20 mines. Among them were many whose proprietor was allegedly Khanifa Dashkova, and those whose "owners" were teenagers Shakir and Zakir. In 1869, the twelve-year-old Shakir, and in 1871, Zakir were recorded as the owners of the property" [Dordemənd, 2003, p. 114]. Thus, in addition to marrying the daughter of Mustafa Burnaev, the richest man in Orsk, at the age of 23 Zakir Ramiev himself, being a "gold miner", was considered to be a worthy young man who, having mastered Turkish and French in Turkey, independently learnt Russian, had excellent Tatar, moreover, he studied Arabic and Farsi in madrassas. According to the facts, in his younger days in Orsk, Zakir got interested in the art of literature. "Upon returning from Turkey, Zakir was engaged in literary work, wrote poetry, translated stories from Turkish and French, he even tried to translate a novel" [Dərdemənd, 2003, p. 106].

Since 1885, Derdemend and his family lived in Orenburg, but he never forgot Orsk and spent every summer working at the local gold mines, often visiting his father-in-law, Mustafa Burnaev. Zakir Ramiev-Derdemend met the beginning of the $20^{\text {th }}$ century in Orenburg, where he founded the newspaper "Vakyt" (1906) and the journal "Shura" (1908). He published them investing his own money and invitd Rizaeddin Fakhreddin from Ufa to assist him in his work. The joint activity of 
Derdemend and R. Fakhreddin during this period left the invaluable rich spiritual heritage...

It is surprising that not only Orenburg, but also Orsk experienced a great national and spiritual upsurge at that time. On July 12, 1907, the fifth mosque was opened there; in 1908, a Muslim library was opened in the city for the first time in history. "In 1914, the Orsk Uyezd had 178 Muslim schools with 213 teachers" [Cherkas, 2003]. In the Orsk region only the Tatars had about 200 madrasah schools and more than 200 teachers, besides Orenburg and the nearest Tatar villages.

In 1911, the Tatar Amateur Theater appeared in Orsk, owing to Mirkhaydar Fayzi's great contribution. The life and work of the playwright, who was 30 years younger than Derdemend, is associated with the Orsk region. He was born in 1891 in the village of Kukshel not far from city. In 1902-1904, he studied at the madrasah in Orsk, then, went to the Khusainiya madrasah in Orenburg, but because of illness he did not complete his studies [Gilyazhev, p. 6]. In 1909, he wrote his first play "Ike Khasan" ("Two Khasans"), it was staged in Orsk by Tatar amateur artists. After that, M. Fayzi started writing dramatic works, poems, and novels, which were published one after another on the pages of Orenburg and Kazan periodicals. In the years 1912-1913, the writer had two printing houses.

As we know, M. Fayzi's father Mustafa worked on the estates of the Orenburg Khusainovs from the village of Kukshel, at the same time, they were known to have their own house in Orsk. "Many residents of the city knew the name of Mirkhaydar Fayzi (1891-1928). He was born and raised in a large family of the tradesman Mustafa Fayzullin, whose House No. 60 was on Pugachev Street. Young Mirkhaydar wrote not only poetry, short stories, and plays, but also staged plays by the Tatar amateur troupe that he created in 19091917" [Cherkas, 2003].

While living in this region, M. Fayzi wrote his immortal works- the dramas "Galiyabanu" (1916), "Asylar" (1920), and "Ak Kalfak" ("White Kalfak") (1922). Derdemend's poetry and Mirkhaydar Fayzi's dramaturgy could be born only among those sincere and glorious Kipchak steppes, the majestic Ural Mountains, the mysterious banks of the Zhaek and Sakmar Rivers. In our opinion, Derdemend knew the playwright personally and was familiar with his work, even though he was much younger.

After being shown on December 27, 1917, at the Orenburg Theater "Nur", "Galiyabanu" was staged in the Orsk "House of Public Assembly". It should be noted that a number of talented actors were bred by this city amateur Tatar theater. "In 1909-1917, the members of the mentioned troupe were Ismagil Muzafarov, Garif Galiakberov, Kh. Gubaidullin, Abdulla Amirov, Khabibulla Sadyikov, Battal Shagidullin, Gibadulla Khasanov, Fayzullin Mirkhaydar (Fayzi), Kamil Salimzyanov and others" [Cherkas, 2003]. And in 1907, into the family of the famous Orsk wealthy man Nigmatzhan Nigmatullin Galia Nigmatullina was born, the mother of the future big artist, Marcel Salimzhanov. M. Salimzhanov's father, the People's Artist of the TASSR Khakim Salimzhanov, was also born in Orsk in 1903. Later, M. Salimzhanov, together with the theater company, arrived in Orsk and visited the places where his parents used to live. The famous composer, violinist Zagid Khabibullin was also born in Orsk in 1910.

The October Revolution of 1917 had a great influence on the lives of national intellectuals, including Derdemend. In 1918, the poet, the large "gold miner", moved from Orenburg to Orsk. What made him take such a step? What did Derdemend die in Orsk in 1921 of - of hunger or of typhus? It should be noted that looking for an answer to this question, we found little information on this subject in mass media. As you know, the Soviet government only reached Orenburg in January 1918, and before that, Zaki Validi had managed to declare "the independent Bashkir selfcontrol". Kazakhs also claimed the lands of the Orenburg region (at that time they were called Kyrgyz) to create their autonomy, but in reality the city was ruled by the chieftain Dutov and his Cossacks. When the Bolsheviks came to power, they closed the newspaper "Vakyt" and the journal "Shura", Derdemend was forced to hand over their buildings to the council members. Deprived of his publishing house, newspaper and journal, Derdemend and Riza Fakhreddin quickly realized what the Bolsheviks really were like and moved, one - to Orsk in February 1918, the other - to Ufa, this temporary relocation being the last one. Through the winter steppe, they were haunted by the lines of Derdemend's poem written ten years earlier, in early 1908, "in which the idea of social difficulties affecting the fate of the country, its people, and government comes to the fore" [Zaidullina, 2006, p. 70] ...

\begin{tabular}{|l|l|}
\hline Шаулый диңгез... & It sees foreign countries \\
Жил өрәдер... & $\ldots$ \\
Жилкәнен киргән & The sea is roaring... \\
\hline
\end{tabular}




\begin{tabular}{|l|l|}
\hline кораб! & The wind's blowing... \\
Төн вә көндез & The ship, raise a sail! \\
Ул йөрәдер: & Both night and day \\
Юл бара ят ил карап... & It's coming: \\
Чыкты жилләр, & The wind gets stronger, \\
Купты тулкын - & The waves rise higher- \\
Ил корабын жил сөрə & The wind is driving the \\
Кайсы юллар, & ship of the country, \\
Нинди упкын & Which roads, \\
Тарта безне жан & What abyss \\
сорап?!. & Is claiming our souls?! \\
[Derdmend, 2003, p. 25] & [Translated by \\
& L. Mukharlyamova] \\
\hline
\end{tabular}

The poet's soul is as sensitive as that of a fortuneteller, he understood that the misfortune that had come to his country would last long, for a very long time. He also felt that he was unable to stop this misfortune, which hung over the people like a black cloud... He came to his world, temporarily, to its steppes and mountains, fleeing the terror that was sweeping the country like the flood of red blood. After studying the events of that period, we have come to the conclusion that "Derdemend left Orenburg feeling internal protest and hate, and disagreeing with the dictatorship of the Bolsheviks". At that time, in Orenburg, there was merciless terror against the rich, they were destroyed without trial.

L. Khamidullin, the writer who lived in Orsk in 1956-1960 and who came there several times more after writing his works about Derdemend, also sees other reasons for the poet's departure from Orenburg. "In addition to the anxiety about the fate of his children, Zakir Ramiev was worried about the mines. In this difficult times, how were things going? Had the mines been destroyed? Were the stone cages with gold in reliable hands?" On the way to Orsk, Derdemend was most probably disturbed by these thoughts. That might have been the reason he decided to go to Orsk without waiting for the roads to be opened. Orsk was the center, which united mining property. If the opportunity arose, Derdemend could get from there to the mines. It might be possible to learn something about his children who were fighting in those parts. In what state were the Orsk banks, with which the Ramievs dealt? [Khamidullin, 2009, pp. 75-76]. All these could be the reasons for Derdemend's departure to Orsk, since it was not so easy to leave the large farm, dozens of gold deposits scattered across the steppe, the cells stored with gold.
As people studying the history of the region write, Derdemend's family lived in Orsk in different places - at his wife's relatives place, in a rented house, and in the village, when a fierce struggle for the city was waged between the White Army and the Red Army. In general, for Derdemend his last stage of life was far from being calm: in the course of 3-4 years, there were revolutions, the civil war, and famine, moreover, his adult children died of typhoid.

In search of the peace of mind and with the desire to save his family from the troubles that plagued the country, Derdemend returned to Orsk but he could not find his family there. By summer, fierce battles for the city had begun, for months it remained cordoned off, it was in the hands of either the Whites or the Reds: in one year, power changed hands four times. "In 1918-1919, during the Civil War, the city withstood a three-month siege, then was captured four times by the warring parties" [en.wikipedia.org> Orsk: accessed: 09/05/2019]. And one after another misfortunes plagued Derdemend's family. As follows from the memoirs of his sister-in-law, Asma RakhmatullinaIbragimova, the poet's son Murad was mobilized and sent to the front by the Whites, and Jagfar - by the Reds. In this war, Murad died of typhoid, Jagfar lost his arm. In the autumn of 1919, Sharifzada, his son Iskander's pregnant wife, died of typhoid, and their one-year-old son Bashir remained in Derdemend's care. (Later this orphan - Bashir Ramiev, became a world famous scientist, an inventor of the first computer in the USSR, doctor of technical sciences, and a State Prize laureate).

The memoirs of Asma RakhmatullinaIbragimova, who lived in Orsk at that time, tell us that when the Reds came to the city, the rich population of Orenburg and Orsk fled, joining the Whites. Thus, not only the Derdemend's family, but also other rich people moved from Orenburg to Orsk, hiding from the Reds. When the Reds got to Orsk, the majority of rich Tatars left this city with the Whites. But Derdemend remained... Let us not talk about such high moral principles as "being loyal to one's country, remaining with one's people", and focus on the bitter reality of life. What should a man like Derdemend do under such conditions? $\mathrm{He}$, who had reached the age of 60 , the head of a large family, with all the remaining children and grandchildren to look after, the poet with a subtle soul, the man who had so far been respected in society? Was it worth while joining the Dutov and Kolchak's Army, joining the 
Russians, and going to wander around the world along with his children and grandchildrenorphans? What was in store for him and his family there?

Derdemend himself answered these questions with a poem written precisely in those bloody, troubled years:

Куанды ил, канат какты мәләкләр,

Шашып, аң-таң булып шайтан төкерде!..

Житәр, жилкенмә, йолкынма, күңел, син,

Кияү булсаң да, ул туйга түгел син!

Жиһан тормыш туен иткән чагында,

Синең урның - үлекләр аймагында

[Derdemend, 2003, p. 219]. wings

The country rejoiced, angels flapped their

The mad demon spat!..

Enough, don't flutter, don't tear your soul,

Even if you are the groom, it is not your wedding!

When the universe celebrates life,

Your place is in the realm of the dead [Translated by L. Mukharlyamova].

Of all the information about Derdemend, only a few poems of that period are known. A. Rakhmatullina-Ibragimova wrote that the unpublished records of the poet had been stolen at the station along with Jagfar wife's suitcase. Even though he felt depressed, life was bitter, and the future was uncertain, Derdemend tried to find his place in society. According to L. Khamidullin's information, at that time he visited Kazan: "During his Orsk period, he was known to visit Kazan once. In January 1919, a conference was organized to improve the Tatar script. Derdemend, who for years had expressed his opinion in mass media regarding the change of spelling, was also invited there " [Dordemənd, 2003, p. 217].

During those years, the city of Orsk suffered from endless wars, typhoid, and later from hunger, but life, in any case, went on. At the beginning of 1918, the Muslim Council was created, in 1919, the second Muslim library was opened, and the Tatar Club began its work. I want to believe that Derdemend took part in these events. When the city was captured by the Reds, the Bolsheviks involved the Tatars, national intellectuals in various organizational work, some of them were elected to senior positions. "At the 1st Orsk District Congress of Soviets on June 28, 1918, the Executive Committee was elected, which included the Tatars: Musin Mukhametsafa Safich and Dautov Abdulla Mukhametzyanovich. Bashkir Tatlybaev Zarif was elected its secretary. Certain work was carried out among Muslim women: their first general meeting was held on September 27, 1919. Zabirova Fatima was elected the organizer of Tatar women. Since October 1919, the Food Department of the city was headed by A. Dautov. In 1920, under the Orsk RCP (B.), a Muslim section was established, then a subdivision of the national minority, which operated until 1927. Amirov was elected its first chairman" [Cherkas, 2010, p. 196].

Derdemend was not among them. In spirit and upbringing, Derdemend was completely different, he could not enter the ranks of the Bolshevik Tatars. At the same time, he maintained communication with the national commissioner Abdulla Davletshin, as this young man began to publish a newspaper in Tatar in the building of the "Club Sharyk" in Orsk.

"Derdemend sometimes visited this building, talked to the young commissar Abdulla Davletshin, who was supposed to work among the national minorities of the region," wrote L. Khamidullin. In 1920, Davletshin began to publish "Irek Yoldyzy" ("The Star of Freedom"), the first national newspaper in Orsk. This weekly two-page newspaper published a literary and cultural corner: poems, literary brocades, and cultural news. In the commissar's room, one could also find newspapers from the center" [Dərdemənd, 2003, p. 218].

As follows from historical sources, the newspaper "Irek Yoldyzy" was published in Orsk from 1919 to 1921. Only a few copies have been preserved in our libraries: in Kazan, in the Central State Historical and Political Documents Archive of the Republic of Tatarstan there is the $12^{\text {th }}$ issue of 1921; in Moscow, at the State Library of the Russian Federation - the $11^{\text {th }}$ issue of 1921; in St. Petersburg, in the National Library of the Russian Federation - the $11^{\text {th }}$ issue of 1921 [Gainanov, Mardanov, Shakurov, pp. 71-72]. L. Khamidullin announced the storage of one issue of the newspaper "Irek Yoldyzy" in the Orsk Museum. In these issues, unfortunately, there is no information about Derdemend, no publications of his poems. Therefore, in the future it is necessary to intensify our searches in this direction.

Thus, Derdemend lived in Orsk for more than three years. His son Iskander, who had been educated abroad, was the right professional for the Soviet Union. He returned to help with the farm, and was offered a job in the gold mines. (However, he was later arrested as an "enemy of the people" and perished in exile). Perhaps it was in this period that the Ramievs transferred all their gold reserves (and there were tons of gold) to the Soviet 
authorities; historians are of the opinion that it was done "voluntarily". In my opinion, the Ramievs were not asked if they wished to share their wealth with the state, as many rich people were pushed out of their houses into the street and shot without trial, their gold was taken away without ceremony. Derdemend was in no hurry to return to Orenburg again, although in 1920-1925 the capital of Kazakh autonomy moved there, and the Kazakhs were not concerned about the rich. At that time, no one encroached on the Ramievs' property in Orenburg. Derdemend spent the last years of his life in Orsk, he lived there, died there, and was buried there... So, it was destined...

L. Khamidullin writes that he heard Derdemend help the people during the famine: "For example, there is evidence concerning Derdmend's voluntary work in 1921: this information was provided by one veteran communist Gabdulla Davletshin, who worked in 1920 in the "Consumer Society", either in the commission against hunger or for charity in the region during the meetings in 1960-70 in Orsk. However, we have no documentary evidence of this information so far" [Bertugan Rəmiievlər, 2002, p. 36]. This fact may match reality, because Derdemend was not a man to remotely observe the misfortunes of other people, while his legs were walking, his words were heeded, he probably resisted hunger. However, this was not a disaster that an ordinary person could solve... Orsk was struck by famine, people died not in hundreds, but in thousands. "A new test was the famine of 1921-1922. In 1920, the population of the city numbered more than 16 thousand people, and by 1923 it had reduced to ten and a half thousand [Orsk. Foto album, p. 22]. Among these thousands there was the only one of its people, Tatar poet Derdemend - the gold miner Zakir Ramiev...

There are several versions of the cause and time of Derdemend's death. As follows from official sources, in the autumn of 1921, the poet went to Orenburg to visit his sick daughter. Having buried her, on the way to Orsk, he caught a cold and soon died. "The great grief, the hardships of the long journey, and the autumn cold undermined his strength," writes L. Khamidullin. - On returning, he was not well for about a week, and on October 9, 1921, Zakir Ramiev-Derdemend died. He was buried in the cemetery of the village Ilyas near the city" [Dordemənd, 2003, p. 218].

Almost all these facts, cited from the source, are true, only the words "he was not well for about a week" are doubtful. And there is a good reason for doubt, as Derdmend's sister-in-law, A. Rakhmatullina-Ibragimova, reports the death of Gulsum, the poet's eldest daughter Ummegulsum, in Orenburg in spring: "In Orenburg, Gulsum's family suffered from hunger in winter, and when spring came, Garif, her son-in-law, brought a frozen watermelon from the market. Gulsum apa ate it hungrily, and died either of abdominal pain, or cholera [Ramievlar, 1999, p. 185].

In these memoirs, there is a new important fact about Ummegulsum's death in Orenburg in spring: it turned out that Derdemend went there in spring. We have no reason to question A. RakhmatullinaIbragimova's words, because she was 16 at that time and remembered everything well. It becomes apparent that Ummegulsum's family was starving in Orenburg. Derdemend brought them some food. The memoirs say that in Orsk the Derdemend family ate only porridge, that is, there was no former rich life, no servants, nothing but porridge cooked by themselves. Naturally, if there was porridge, there was no hunger, but this fact proves that the supply of food in the house had run out.

Thus, Derdemend went to Orenburg to his eldest daughter in the spring of 1921 . He collected his orphaned grandchildren, but fell ill on the way home, and was laid up for another six months. When Z. Ramiev was ill, R. Fakhreddin is known to have visited him. This meeting would not have been possible had Derdemend been ill for one week, since Riza Khazrat lived in Ufa. R. Fakhreddin writes the following about his last meeting with Derdemend: "On the way from Orenburg to Ufa I stopped by to say goodbye. The sick poet was lying in bed. I stayed for a while as he assured that "he was getting better" and realizing that he wanted to talk a little. "Khazrat! If things improve, we will repeatedly issue "Vakyt" and "Shura", we hope and ask for things to return to the previous times in Orenburg, we also want to make Hajj, we have already discussed this with you," he said. "May Allah give this to us," I promised to fulfill his wish and left. This was our last meeting [Fakhreddin, 2010, p. 354)].

When and where this meeting took place is not known for certain, but it is quite logical to assume that it took place when Derdemend was dying. As we know, at the end of February 1918, one of them went to Ufa, the other left Orenburg for Orsk, the poet was not dying, moreover, he lived for more than three years afterwards. This means that this last meeting took place in 1921, but the exact date is not known. This was their last meeting, the farewell of two great people, two sons of their na- 
tion. The last moments of his life Derdemend was worried about the national printing house, he dreamed of reviving the newspaper "Vakyt" and the journal "Shura". He planned Hajj together with Rizaeddin Khazrat, as can be seen from their conversation, they had discussed it before. Therefore, neither Derdemend, nor Rizaeddin Fakhreddin Khazrat had performed Hajj before? No such information has been found.

There is more evidence to substantiate $\mathrm{L}$. Khamidullin's words that "Derdmend went to his eldest daughter in Orenburg in autumn". Fatykh Karimi, who knew Z. Ramiev closely, worked as editor-in-chief in the newspaper "Vakyt". In 1927, he wrote the following about Derdmend's death: "On returning from Orenburg in October 1921, he caught a cold, died on October 9 in Orsk, and was buried there. He was 62 years old" [Karimi, 1928, p. 17].

Zaki Validi is also known to have visited sick Derdemend in Orsk: he noted that the poet was not worried about himself, but about the nation. Any information about the time of Z. Validi's last meeting with Derdemend could clarify the situation.

The cause of the Tatar poet Derdemend's death gives rise to many questions: did he die of starvation or typhus? Typically, these two adversities happen simultaneously. From the memoirs of A. Rakhmatullina-Ibragimova it follows that no members of the family died of hunger in Orsk, if it were so, she would have written. Her 18-year-old sister Sarah died of typhoid in 1921: "My brother-in-law has given the mother money for the burial and brought three sheep". "No sooner had we recovered from the grief of death, another misfortune came: my brother-in-law went to Orenburg to visit his eldest daughter, Gulsum apa, and to bring them food" [Ramievlar, 1999, p. 185], - continues Asma Rakhmatullina-Ibragimova.

The fact that Derdemend took food to Orenburg indicates that the family did not suffer from hunger at that time. However, the family could have suffered from famine in autumn. The exact date of Ummegulsum's death could clarify this issue. "My brother-in-law was very cold during his journey back, because the trains were not heated," writes the author of the memoirs. "Having developed bronchitis, he could not recover and died. The doctor said that his heart was weak..." [Ramievlar, 1999, p. 185]. Yes, it could be both a heart disease, and bronchitis, which became pneumonia, and typhoid, and hunger.
Derdemend, a poet with a sad pseudonym, foresaw more terrible times coming and left this unjust world. He calmly passed away on his land, in his family, among his closest ones, they said a prayer for the deceased according to Islamic law and buried him. During the war, a military factory was built in the place of the Tatar cemetery where he was resting, rockets were made over his grave, but the poet's soul left that close grave a long time ago and went to Allah... As parting words to the nation, the noble poet of the Tatar people Derdemend wrote the following lines before his death: "What remains is people born and living here, they remember the glory of their ancestors, pass them on from generation to generation". In this poem, Derdemend speaks of himself and his attitude to his people [Frederikh, 2014, p. 99].

\begin{tabular}{|l|l|}
\hline Гөрләгән сулар & On swirling water, \\
башында, & Look here, it will pass - \\
Тыңлагыз, шунда үтәр & If sunrise walks in tears \\
- & And the dream is in sor- \\
Йөрсә сыктап таң- & row. \\
сәхәрләр & Oh, the air of my land, \\
Моң-сагышлардан & I'm not offended, please \\
хыял. & rise! \\
И туган илнең hавасы, & I'm not offended, please \\
Рәнжемим, зинhар & rise! \\
күтәр! & What is close - this Fa- \\
Рәнжемим, зинhар & therland? \\
күтәр! & Ah, my family is native! \\
Ни газизрәк - бу ва- & What is equal to sacred \\
танмы? & blood \\
Аһ, туган каүмем га- & And sacred milk!.. \\
зиз! & Milk will stay, Father- \\
Ул мөкаддәс кан белән & land will leave! \\
ул & Milk will stay, \\
Изге сөткә ни житәр!... & Fatherland will leave! \\
Сөт калыр, ватан & [Translated by \\
китәр! & L. Mukharlyamova] \\
Сөт калыр, ватан & \\
китәр! & \\
[Dеrdетеnd, 2003, & \\
р. 61] & \\
&
\end{tabular}

Thus, the Orsk region occupies a special place in the scientific biography of the great thinker, the respectable public figure Derdemend, who made a great contribution to the social and spiritual upsurge of the Tatar people, the renewal of national verbal art. The important events of his life took place in this city that significantly affected the fate of the poet. Here, his personality was shaped and he grew up as a creative person. In Orsk, he 
created a family, became a large gold miner in the Russian gold industry, realized his true identity as a patriot. Later, he actively participated in the cultural and political life of the region, determined the progress and direction of the Tatar people's development. When times changed after 1917, the troubled and hard times began, Orsk became a corner of refuge for him and his family. The last hours of Derdemend's life passed here; here, he set off for another world.

\section{References ${ }^{1}$}

Abelgazyi, Bahadir khan (2007). Shazhrai torek [Turks Genealogy]. 134 p. Kazan, Tatar. kit. nashr. (In Tatar)

Battalov, G. A. (1996). Kazan torkilare. Tarikhi iazmalar [Kazan Turks. Historical Notes]. Per. A. Rakhimova; red. L. Khamidullin. 192 p. Kazan, Tatar. kit. nashr. (In Tatar)

Bertugan Ramiievlar: Fanni-biografik жyyentyk (2002) [Ramiev Brothers: Scientific-biographic Collection]. 368 p. Kazan, Rukhiiat. (In Tatar)

Cherkas, T. G. (2005). Khronograf goroda [The Chronicle of the City]. 67 p. Orsk: Orskiy istorikokraevedcheskii muzei. (In Russian)

Cherkas, T. G. (2003). Musulmane Orska v 19nachale 20 veka [Orsk Muslims in the $19^{\text {th }}-$ Early $20^{\text {th }}$ Century]. Orskie izvestiia (vkladysh "Tugan tel"). January 28. (In Russian)

Cherkas, T. G. (2010). Orsk: ot kreposti do goroda [Orsk: From the Fortress to the City]. Monografiia. 263 p. Orsk, OGTI. (In Russian)

Dautov R. N., Nururllina N. B. (1986). Дәрдемәнд. Sovet Tatarstany iazuchylary: biobibliografik beleshme [Derdemend. Writers of the Soviet of Tatarstan: The Bibliographic Reference]. Pp. 165-166. Kazan, Tatar.kit.nashr. (In Tatar)

Dardemənd (2003). Keresh suz avt. L. Khamidullin; toz., fotoresemner hem maket avt. Z. Bashirov. 239 p. Kazan, Tatar.kit.nashr. (In Tatar)

Dordemənd (1980). Ise zhiller: Shigrlar. Istelekparchalar. Vak khikeyeler [Winds Are Blowing: Poems. Memory-fragments. Short Stories]. Toz. hem isk. iazuchy R. Dautov. 254 p. Kazan, Tatar.kit.nashr. (In Tatar)

Friderikh, M. (2014). Donia edebiiaty kontekstynda Dordemand izhaty [Dardmend's Poetry in the Contxt of World Literature]. TATARICA. No. 2 (3), pp. 85-105. (In Tatar)

Fakhreddin, R. (2006). Asar [Works]. T. 1. 359 p. Kazan, Rukhiiat. (In Tatar)

Fakhreddin, R. (2009). Asar [Works]. T. 2. 303 p. Kazan, Rukhiiat. (In Tatar)

\footnotetext{
${ }^{1}$ In addition to the works presented in the References, we used the records of the bulletin "Orsk Tatars", published in Orsk in 2009-2013, and Internet articles related to the history of the region.
}

Fakhreddin, R. (2010). Asar [Works]. T. 3, 4. 646 p. Kazan, Rukhiiat. (In Tatar)

Gainanov, R. R., Mardanov, R. F., Shakurov, F. N. (1999). Tatar vakytly matbugaty (1905-1924) [Tatar Media (1905-1924)]. Казан. (In Tatar)

Gilazov, T. Sh. (2014). Poeziia Dardemanda v kontekste Zapada i Vostoka [Derdemend's Poetry in the East and the West Contexts]. Vestnik ChelGU. Filologiia. Iskusstvovedeniie. No. 10 (399), pp. 46-51. (In Russian)

Gilyazhev, T. Sh. (2017). Mirkhaidar Faizi dramaturgiiase [Mirkhaydar Faizi's Dramaturdy]. Pp. 5-48. Kazan, Tatar. kit. nashr. (In Tatar)

Ignatev, R. P. (1868). Drevnie zdaniia v Trotsom uezde Orenburgskoi gubernii [Ancient Buildings in the Trotsky District of the Orenburg Province]. Orenburgskie gubernskie vedomosti. No. 21. (In Russian)

Iskandarov, R. Sh. (2009). Orenburgskie Tatary: istorico-entsiclopedicheskii ocherk [Orenburg Tatars: A Historical and Encyclopedic Essay]. 271 p. Kazan, Tatar. kn. Izdat. (In Russian)

Iskandar ham Bashir Ramievlar (1995) [Iskander and Bashir Ramievs] Төз. M. Rəhimkulova. Orenburg, Iana vakyt. (In Tatar)

Karimev, F. (1928). Dardemand (1859-1921) [Derdemend (1859-1921)]. Derdmend eserlere. Төз. I. Rəmi. Pp. 8-18. Kazan, Ianalif. (In Tatar)

Khabutdinova, M. M. (2005). Klad Derdemenda [Derdemend's Treasure]. Idel. No. 9, pp. 57-59. (In Russian)

Khabutdinova, M. M. (2006). Tvorchestvo Derdemenda $v$ aspekte dialoga kultur (na primere analiza stikhotvoreniia "Karab" ("The Ship") (1908)) [Derdemend's Works in Terms of a Dialogue among Cultures (based on the analysis of his poem "The Ship" (1908))]. Dialog kultur: russko-tatrskie vzaimosviazi. Materialy istoriko-filologicheskogo seminara Vserossiiskoi nauchno-prakticheskoi konferentsii "Slavianskaia kultura: istiki, traditsii, vzaimodeistvie" 7 Kirrilo-Mefodievskikh chtenii. Vypusk 2. MoskvaIaroslavl', Remder, pp. 86-92. (In Russian)

Khalit, G. (1986). Dardemand [Derdemend]. Tatar edebiiaty tarikhy. Alty тоmda: 20 gasyr bashy. Pp. 194214. Kazan, Tatar.kit.nashr. (In Tatar)

Khisamov, N. (1989). Dardemand: tormyshy hem izhaty turynda ocherk [Derdemend: An Essay on His Life and Works]. Kazan utlaty. 312. Pp. 165-175. (In Tatar).

Khamidullin, L. (2009). Kichke shefek [Evening Dawn]. Documental povest, esse, ocherklar. 255 p. Kazan, Tatar.kit.nashr. (In Tatar)

Orenburgskaia guberniia. Spisok naselennykh mest po svedeniyam 1866 goda (1871) [The Orenburg Province. The List of Settlements According to the Information of 1866]. Sost. i izd. Tsentr. Stat. com. M-va vnutr. del; obrab. V. Zverinskim. St. Petersburg izd-vo tsentr. stat. com. m-va vnutr. del, 108 p. (In Russian)

Orenburgskii listok. [The Orenburg Paper]. Orenburg 1887. September 18. (In Russian) 
Orsk: Fotoalbom (1995) [Orsk: A Photo Album]. Lit. tekst: V.Lavrik; Fotoil.: V. Tikhomorov, V. Scherbakov; Pod obsch.red. V. Scherbakova. 107 p. , il.; 24 sm. Moscow. (In Russian)

Popov, S. A. Rukopis [A Manuscript]. OIKM, inv. No. 29/115a. (In Russian)

Popov, S. A. (1982). Tainy piatimarov: ocherki po drevnei I srednevekovoi istorii Orenburgskikh stepei [Secrets of the Pyatimars: Essays on the Ancient and Medieval History of the Orenburg Steppes]. Red. N. T. Struzdyumov, E. V. Novskii. 2 izd., ispr. i dop. 246 p. Cheliabinsk, Yuzh.-Ural. kn. izd-vo. (In Russian)

Ramievlar (1995) [The Ramievs]. Toz. M. Rakhimkulova. 96 p. Orenburg, Iana Vakyt. (In Tatar) Ramievlar (1999) [The Ramievs]. Toz. M.

Rakhimkulova. Orenburg, Iana Vakyt. (In Tatar)

Rizaetdin bin Fakhretdin (1998). 250 p. Orenburg.

(In Tatar)

ORSK // ru.wikipedia.org 2019-2019. URL: https://ru.wikipedia.org/?oldid=103782319 (accessed: 05.09.2019)

Rychkov, P. I. (2001). Istoriia Orenburgskaia [Orenburg History]. Ufa, TsEI UNTs RAN, 201 p. (In Russian)

Rychkov, P. I. (1999). Topografiia Orenburgskoi gubernii [The Orenburg Province Topography]. Komm. I. V. Kuchumova, F. A. Dhakurovoi]. 439 p. Ufa. (In Russian)
Saiapova, A. M. (2014). Derdemend $i$ filosofiia ekzistentsializma [Derdemend and Existentialism Phylosophy]. TATARICA. No. 2(3), pp. 68-84. (In Russian)

Saiapova, A. M. (1997). Poezia Dardmenda $i$ simvolizm [Derdemend's Poetry and Symbolizm]. 210 p. Kazan, Kazanskii ped. un-t. (In Russian)

Shakurov, F. (2002). Razvitie istoricheskikh znanii u Tatar do Fevralia 1917 goda [Develpoment of Historical Knowledge in Tatars till February 1917]. 128 p. Kazan, izd-vo Kazan. un-ta. (In Russian)

Smirnov, K. F. (1975). Sarmaty na Ileke [The Sarmats on the Ilek]. 176 p. Moscow, Nauka. (In Tatar)

Sobolevskaya, O. V. (2003). Biografiia [Biography]. Literaturnaia entsiklopediia termonov i poniatii [gl. red. i sost. A. N. Nikoliukin]. Pp. 90-91. Moscow, NPK "Intelvak". (In Russian)

Tatary $v$ Orengurgskom krae (1997) [Tatars in the Orenburg Region]. 228 p. Orenburg, izd-vo "Dimur". (In Russian)

Valetdinov, R. (2010). Orsk Tatarlary [Orsk Tatars]. May, No. 5. (In Tatar)

Zagidullina, D. F. (2006). Donia surate uzgaru: 20 ioz bashy Tatar edebiiatynda felsefi eserlar [Chaning the Image of World: Philosophic Works in Tatar Literature in the Early 20 ${ }^{\text {th }}$ Century]. Monografia. $191 \mathrm{p}$. Kazan, Magarif. (In Tatar)

\title{
ЗАТЛЫ ШАГЫЙРЬ ДӘРДЕМӘНД: ОРСК ЧОРЫ ТОРМЫШЫ, ЯНА ФАКТЛАР ҺӘМ УЙЛАНУЛАР (ТУУЫНА 160 ЕЛ ТУЛУ МӨНӘСӘБӘТЕ БЕЛӘН)
}

\author{
Фәүзия Әүхәди кызы Бәйрәмова, \\ Татарстан Язучылар берлеге, \\ Россия, 420015, Казан ш., Мөштәри ур., 14 нче йорт, \\ ittifak@yandex.ru.
}

\begin{abstract}
Мәкаләдә татар халкының күренекле шагыйре, милләтпәрвәр, алтын приискалар хужасы Дәрдемәнднең (Закир Рәмиевнең) Орск чоры тормышы өйрәнү объекты булып тора. Татар әдәбият белемендә шагыйрьнең фәнни биографиясе нигездә эшләнсә дә, Ф. Кәрими, Р. Фәхреддин, М. Гайнуллин, М. Рәхимкулова, Л. Хәмидуллин һәм дә Орск төбәген өйрәнүче Т. Г. Черкас хезмәтләренә таянып, Дәрдемәнднең Орск чоры яңа фактлар белән тулыландырыла, аерым мәсьәләләргә карашлар яңартыла. Бу шәһәрдә 3. Рәмиевнең үсмер чагы һәм яшьлеге үтеп, аның киңкырлы, затлы шәхес буларак формалашуы ассызыклана. Орск төбәгенең татар галәмендә талантлы һәм оригинал шагыйрь буларак танылу алган һәм Россия алтын чыгару санагатендә мөһим роль уйнаган Дәрдемәнднең мәдәни һәм сәяси тормышына сизелерлек йогынты ясавы күрсәтелә. 1917 елгы Октябрь борылышыннан соң, гомеренең соңгы елларында шагыйрьнең Орск шәһәре белән бәйләнеше ачыла.
\end{abstract}

Төп төшенчәләр: татар поэзиясе, шагыйрь, алтынчы, биография, Орск шәһәре, Дәрдемәнд.

\begin{abstract}
Соңгы елларда әдәбият белемендә ижат кешесенең дөнья масштабында яки үз халкының мәдәнияте, әдәбияты тарихындагы hәм ижтимагый-сәяси тормышындагы
\end{abstract}

кыйммәтен билгеләү өчен, биография жанрына еш мөрәжәгать ителә башлады. Биография «кешенең индивидуаль биографик тәжрибәсендәге ижтимагый мәгънәле 
эшчәнлегенең тамырларын эзләүгә һәм ачыклауга юнәлгән шәхси тормыш тарихын әдәби яки гыйльми аңлатуны күздә тота» [Соболевская, с. 90]. Дәрдемәнд ${ }^{1}$ (Закир Рәмиев, 1859-1921) шигърияте әдәби-эстетик үзенчәлекләре белән генә түгел, ә ижтимагый хәле белән дә татар тарихында ялгыз урында тора. Ижатында, татар поэзиясенең күпгасырлык традицияләренә нигезләнеп, аны яңартып кына калмыйча, дөнья масштабына чыгарган шагыйрь рухи мирасының өйрәнелү тарихы гажәеп бай. Әдәбиятчы галимнәр Дәрдемәнд шигъриятендә шәрык һәм гареб мәдәниятләренә хас әдәби-эстетик һәм фәлсәфи концепцияләр һәм системалар гәүдәләнешен билгелиләр [Халит, 1986], [Хисамов, 1989], [Заһидуллина, 2006], [Саяпова, 1997], [Хабутдинова, 2005], [Хабутдинова, 2006], [Саяпова, 2014], [Фридерих, 2014], [Гилазов, 2014] h.б.лар. Татар әдәбият фәнендә Дәрдемәнднең фәнни биографиясе нигездә төзелгән, әмма аның тормыш юлындагы аерым чорларны яңа фактлар белән тулыландыру, моңа кадәр күләгәдә кала килгән вакыйгаларны ачыклау һәм кайбер мәсьәләләр хакында бәяхөкемнәрне үзгәртү сорала. Мәкаләдә шагыйрьнең Орск чоры тормышы шушы ноктадан тикшерелә.

Дәрдемәнднең бай һәм катлаулы тормышында Орск төбәге аерым урын тота. Бу шәһәр белән шагыйрь гомер юлының төрле баскычлары үзара бәйләнгән. Биредә аның шәхси тормыш фактлары гына түгел, ә татар халкының ижтимагый үсешен һәм рухи-мәдәни яңарышын тәэмин иткән вакыйгалар бер-берсе белән тоташа. Фәнни хезмәтләрдә Орск чоры аның соңгы еллары һәм үлеме белән генә бәйләнә, ә бит бу шәһәрдә шагыйрьнең үсмерчагы һәм яшьлеге дә үтә! Дәрдемәнднең биографиясе, кызганычка каршы, хронологик тәртиптә, елын-елга салып төзелмәгән, шуңа күрә аның фәнни биографиясен төзү өчен төрле чыганакларга мөрәжәгать итәргә туры килә. Мәгълүм булганча, Дәрдемәнд 1859 елда Көньяк Уралда урнашкан Жиргән авылында туа, аннан аңа өч яшь вакытта гаиләләре Юлык авылына күченә. Булачак шагыйрь Дәрдемәнд Мөхәммәдзакир Рәмиев, үзеннән 2 яшькә олы

11985 елларга кадәр нәшер ителгән хезмәтләрдә Дәрдмәнд язылышы фәнни куланылышта була. Соңгы елларда Дәрдемәнд варианты файдаланыла башлады. Мәкаләдә үзгәртеп коруларга кадәр чыккан хезмәтләр хакында сүз барганда, алардан алынган цитаталарда Дәрдмәнд язылышы сакланды. абыйсы Мөхәммәдшакир белән башта Юлык авылы мәдрәсәсендә башлангыч белем ала һәм аннан соң укуларын Орскида дәвам итәләр.

«Алар үскәндә Юлыкта башлангыч (ибтидаи) мәктәп кенә була, - дип яза Л. Хәмидуллин. - Шуннан соң алар ике кыш Орск шәһәрендә укыйлар» [Дәрдмәнд, 2003; 75 б., 94 б.]. Мәкаләдә абыйлы-энеле Рәмиевләрнең Орскида укыган еллары төгәл күрсәтелмәгән, мантыйк буенча, ул 1870 елларның башына туры килә, үсмер малайларга ул чакта 12-13 яшь була. Бу хактагы аерым фактлар Ризаэддин Фәхреддин хезмәтендә ачыклана: «Шакир әфәнде ибтидаи тәхсыйлен (башлангыч белемне. - Ф. Б.) Йулык карьясендә (авылында. - Ф. Б.) кылып, Орски шәһәрендә дамелла Гариф Мәгази мәдрәсәсендә вә андан соң Сакмар елгасы буендагы Муллакай авылында Габдулла бине Сәед хозурында булган. 1874 елда укудан туктаган» [Фәхреддин, 2010; 422423 б.]. Димәк, Закир һәм Шакир Рәмиевләр Орскида дамелла Гариф Мәгази мәдрәсәсендә белем алалар.

Оренбург-Орск төбәге татар зыялыларының тормыш сукмакларын, әдәби һәм мәдәни эшчәнлекләрен жентекле тикшереп, аларны яңа фактлар белән баеткан Л. Хәмидуллинның фәнни эшчәнлегендә Рәмиевлар буынының да яңа яклары ачыла. Ул Дәрдемәнднең Орск чоры хакында болай дип яза: «Муллакай мәдрәсәсен тәмамлагач, Рәмиевләр кабат Орскида яши, белем үзләштерүне дәвам иттерәләр. Закир моннан Төркиягә китә һәм ике ел чамасы Истанбулда яшәгәннән соң, 1881 елда шунда әйләнеп кайта» [Дәрдмәнд, 2003; 94 б.]. Тексттан аңлашылганча, Муллакай мәдрәсәсен тәмамлагач та (ул 1874 елда була), абыйлыэнеле Рәмиевләр 1875-1880 елларда Орскида яшәүләрен һәм белем үзләштерүләрен дәвам итәләр. Бу вакытта 16-20 яшьләрдә булган Закирнең үсмер һәм яшьлек чоры Орск шәһәрендә үткән, Истанбул чоры кыска булу сәбәпле, ул шушында шәхес буларак та формалашкан дигән нәтижә ясарга мөмкин.

Дәрдемәнд Орскины беренче мәртәбә күргәндә, биредә мәчет һәм мәдрәсәләр була, 2 меңнән артык мөселман яши, шәһәрдә урысларның да чиркәүләре, мәктәпгимназияләре, почта, хастаханә, судлар, полицияләре эшләп тора, таможнясы, гаскәриләре була. Татар байлары шәһәрдәге төп капиталны үз кулларында тоталар, тирә-яктагы сахра-далаларда алтын табылгач, бу приискаларга хужа булып, дөнья белән сәүдә 
итәләр. Безнең карашыбызча, 3. Рәмиевнең Төркиягә укырга китүендә дә шушы бай татарларның тәэсире һәм ярдәме булган.

Игътибар итик: 1881 елны Төркиядән кайткач, Дәрдемәнд Юлыкта түгел, ә Орскида яши башлый, ягъни Рәмиевләрнең бу шәһәрдә Үз йортлары булган. Ш. Рәмиевнең дә 1900 елга кадәр гаиләсе белән биредә яшәве мәгълүм. Бу факт Р. Фәхреддин язмаларында да, төбәк тарихын өйрәнүчеләр тарафыннан да раслана: «В Орске в конце 19 века проживала семья золотопромышленников Рамиевых - им принадлежали прииски в Орском уезде» [Черкас, 2003]. Л. Хәмидуллин Закирның Орск чоры тормышындагы түбәндәге әһәмиятле вакыйганы искәртә: «Чит илдән кайткач, Закир берникадәр вакыт Орскида яши. Сәүдә эшләре белән шөгыльләнә, жәй айларын, гадәттәгечә, алтын приискалары бистәләрендә уздыра. Төркиядән кайтуының икенче елында ул Орскиның зур сәүдәгәре Мостафа Муса улы Борнаев кызы Мәхүбжамалга (1861-1943) өйләнә» [Дәрдмәнд, 2003; 95 б.].

Ырынбурның танылган мәгърифәтчесе Мәдинә Рәхимкулова нәшер иткән китапларда Мәхүбжамалның 1864 елда тууы һәм Татар Каргалысыннан булуы күрсәтелә [Рәмиевләр, 1999; 27 б.]. Дәрдемәнднең балдызы Әсма Рәхмәтуллина-Ибраһимованың истәлекләрендә дә шагыйрьнең өйләнүе языла: «Езни (жизни) Туганым абыстайны 16 яшендә ала. Бик яшьли Туганым абыстайны алып, үзе укыта, тәрбия бирә» [Рәмиевләр, 1999; 180-181 б.].

Дәрдемәнднең кайнатасы Мостафа Борнаев Орскиның иң зур байларыннан исәпләнеп, төбәктә сәүдә эшләрен киң жәелдерә, ярты шәһәр аның туган-тумачаларыннан тора. Ул, әлбәттә, үзенең кызын кулында зур малы, капиталы булган, алтын приискалары хужасы Мөхәммәдсадыйк Рәмиевнең улына биргән. Л. Хәмидуллинның язуынча, ул беренче алтын приискасын 1869 елда, аннан соң «көчен дә, малын да жәлләмичә», ел саен берничә алтын «учагы» сатып алган: «Тарихи рәсми язмаларга караганда, М. Рәмиев Үз гомерендә егермедән артык приискага ия булган. Алар арасында Хәнифә Дашкова исеменә язылганы да, яшүсмер Шакир белән Закир „хужа“ булып исәпләнгәннәре дә байтак. 1869 елда унике яшьлек Шакир, 1871 елда Закир милек хужалары булып теркәлгәннәр» [Дәрдмәнд, 2003; 114 б.]. Шулай итеп, 23 яшендә Орскиның иң зур бае Мостафа Борнаев кызына өйләнгәндә, Закир Рәмиев үзе дә «алтынчы кияү» була; аның өстенә Төркиядә укып кайтып, анда төрек-француз телләрен Үзләштергән, русчага үзлегеннән дәресләр алган, татарчасы гаять камил булган, гарәпчә hәм фарсычага мәдрәсәдә өйрәнгән затлы егетләрдән санала. Мәгълүматларга караганда, ул Орскидагы яшьлек чорында ижат белән дә шөгыльләнә башлый. «Төркиядән кайткач, Закир әдәби ижат эше белән шөгыльләнә, шигырьләр яза, төрек, француз телләреннән хикәяләр, хәтта бер роман да тәржемә итеп карый» [Дәрдмәнд, 2003; 106 б.].

Дәрдемәнд һәм аның гаиләсенең 1885 елдан соңгы тормышлары Ырынбурда дәвам итә, әмма ул Орскины да ташлап бетерми, hәр жәйне бу тирәдәге алтын приискаларында эшләп үткәрә, кайнатасы Мостафа Борнаев йортында да еш кунак була. XX гасыр башын Закир Рәмиев-Дәрдемәнд Ырынбурда каршылый, ул анда «Вакыт» газетасына (1906) həм «Шура» журналына (1908) нигез сала, аларны Үз акчасына нәшер итә, Ризаэддин Фәхреддинне Уфадан чакыртып китереп, шушы юнәлештә бергәләп эшли башлыйлар. Дәрдемәнд белән Р. Фәхреддиннең бу чордагы уртак эшчәнлеге милләтебезгә бәяләп бетергесез бай рухи мирас калдыра...

Шунысы гажәп: бу чорда Ырынбур гына түгел, Орск та милли һәм дини яктан зур күтәрелеш кичерә. 1907 елның 12 июлендә биредә бишенче мәчет ачыла, 1908 елда шәһәрдә тарихта беренче тапкыр мөселман китапханәсе үзенең ишекләрен ача. «В 1914 году в Орском уезде насчитывались 178 мусульманских школ при 213 учителях» [Черкас, 2003]. Орск төбәгендә генә дә, Ырынбурны һәм ул тирәләрдәге татар авылларын кертмичә, татарларның ике йөзгә якын мәктәпмәдрәсәләре һәм ике йөздән артык мөгаллимнәре булган.

1911 елда Орскида татар үзешчән театры барлыкка килә, монда Мирхәйдәр Фәйзинең дә зур өлеше барлыгын әйтеп үтәргә кирәк. Дәрдемәндтән 30 яшькә яшьрәк драматургның гомере һәм ижаты Орск төбәге белән бәйле. Ул биредән ерак булмаган Күкшел авылында 1891 елда туа, 1902-1904 елларда Орскида мәдрәсәдә укый, аннан белемен Ырынбурның «Хөсәения» мәдрәсәсендә дәвам итә, ләкин авыру сәбәпле аны тәмамлый алмый [Гыйлажев, 2017; 6 б.]. 1909 елда ул «Ике Хәсән» дип аталган беренче пьесасын яза, аны Орскида татар үзешчәннәре белән сәхнәдә уйныйлар. Шуннан соң $M$. Фәйзи бер-бер 
артлы Ырынбур һәм Казан матбагасы битләрендә дөнья күргән драма әсәрләре, шигырьләр, хикәяләр яза башлый. Язучының 1912-1913 елларда хәтта ике жыентыгы да басылып чыга.

Билгеле булганча, М. Фәйзинең әтисе Мостафа Ырынбур байлары Хөсәеновларның Күкшел авылындагы утарларында идарәче була, шул ук вакытта аларның Орскида да үз өйләре булганлыгы билгеле. «Многие орчане знают имя Мирхайдара Файзи (1891-1928 г.г.). Он родился и вырос в многодетной семье мещанина Файзуллина Мустафы, дом которого находился на ул. Пугачева, 60. Юный Мирхайдар не только писал стихи, рассказы, пьесы, но и ставил спектакли созданной им татарской любительской труппой в 1909-1917 гг.» [Черкас, 2003].

М. Фәйзи бу төбәктә үзенең үлемсез әсәрләрен - «Галиябану» (1916), «Асылъяр» (1920), «Ак калфак» (1922) драмаларын яза. Дәрдемәнд шигърияте һәм Мирхәйдәр Фәйзи драматургиясе бары тик шушы моңлы һәм шанлы кыпчак далаларында, мәгърур Урал тауларында, серле Жаек һәм Сакмар су буйларында гына туа ала. Безнең карашыбызча, үзеннән күпкә яшь булса да, Дәрдемәнд драматургның үзен дә, ижатын да белгән, хәерхак та булган.

1917 елның 27 декабрендә Ырынбурның «Нур» театрында куелганнан соң, «Галиябану» Орскиның «Дом общественного собрания» сәхнәсендә уйнала. Шунысын да әйтергә кирәк: шәһәрнең бу үзешчән татар театрыннан талантлы артистлар үсеп чыга. «В 1909-1917 гг. участниками упомянутой труппы были Исмагил Музафаров, Гариф Галиакберов, X. Губайдуллин, Абдулла Амиров, Хабибулла Садыйков, Баттал Шагидуллин, Гибадулла Хасанов, Файзуллин Мирхайдар (Файзи), Камил Салимзянов и другие» [Черкас, 2003]. Ә Орскиның танылган бае Нигъмәтжан Нигъмәтуллиннар гаиләсендә 1907 елда булачак зур артистка, Марсель Сәлимжановның әнисе Галия Нигъмәтуллина туа. М. Сәлимжановның әтисе, ТАССРның халык артисты Хәким Сәлимжанов та 1903 елны Орскида туа, соңыннан М. Сәлимжанов театр коллективы белән Орскига килеп, әти-әнисенең туган-торган нигезләрен күреп китә. Танылган композитор, скрипкачы Заһид Хәбибуллин да 1910 елда Орскида туган.

1917 елгы Октябрь борылышы милли зыялылар тормышына, шул исәптән
Дәрдемәндкә дә зур йогынты ясый. 1918 елда шагыйрь, эре «алтынчы» Ырынбурдан Орскига күчә. Аңа бу адымны ясарга нәрсә мәжбүр иткән? 1921 елда Дәрдемәнд Орскида нидән үлгән - ачлыктанмы, тифтәнме? Бу сорауларга жавап эзләгәндә, кулыбызда, гомумән, матбугатта моңа кагылышлы материалның бик аз булуын әйтеп үтәргә кирәк. Билгеле булганча, Ырынбурга Совет власте 1918 елның гыйнварында гына килеп житә, ә аңа кадәр Зәки Вәлиди биредә «мөстәкыйль Башкорт мохтарияте» игълан итеп өлгергән була. Ырынбур төбәгенә казахлар да (ул вакытта кыргызлар дип аталган) дәгъва кыла hәм үз автономияләрен төзи, ә чынлыкта шәһәр белән атаман Дутов һәм аның казаклары идарә итә. Большевиклар хакимияткә килү белән, «Вакыт» газетасын hәм «Шура» журналын яптыралар, Дәрдемәнд аларның биналарын совет вәкилләренә $\mathrm{Y}^{3}$ куллары белән тапшырырга мәжбүр була. Нәшриятсыз, газета-журналсыз калган, большевикларның асылларын тиз аңлап алган Дәрдемәнд һәм Риза Фәхреддин, 1918 елның февралендә берсе - Орскига, икенчесе Уфага күчеп китәләр, бу вакытлыча китүләре мәңгелеккә була. Дәрдемәнднең моннан ун ел элек, 1908 елның башында язылып, «ил, халык, дәүләт язмышына ижтимагый авырлыклар тәэсир итү фикере алгы урынга чыккан» [Заһидуллина, 2006; 70 б.] шигырь юллары кышкы дала буйлап аларны озата бара...

\begin{tabular}{|l|l|}
\hline Шаулый диңгез... & Чыкты жилләр, \\
Жил өрәдер... & Купты тулкын - \\
Жилкәнен киргән & Ил корабын жил сөрә \\
кораб! & Кайсы юллар, \\
Төн вә көндез & Нинди упкын \\
Ул йөрәдер: & Тарта безне жан \\
Юл бара ят ил карап... & сорап?!. \\
& [Дәрдмәнд, 2003; 25 б.] \\
\hline
\end{tabular}

Шагыйрь жаны әүлиядәй сизгер, ул ил өстенә килгән бу афәтнең әле озак, бик озак дәвам итәсен белә. Кара болыт булып милләт өстенә ябырылган бу фажигане туктата алмасын да сизә ул... Ул Үз дөньясына китә, кызыл кан булып илне басып барган кызыл террордан качып, вакытлыча булса да, далаларына-тауларына китә. Бу чордагы хәлләрне өйрәнгәннән соң, миндә, «Дәрдемәнд, Ырынбурдан большевиклар диктатурасы белән ризалашмыйча, шуңа эчке нәфрәт һәм протест йөзеннән киткән икән» дигән фикер туды. Ул чорда, Ырынбурда байларга карата рәхимсез 
террор сәясәте алып барылып, аларны судсызнисез юк иткәннәр.

1956-60 елларда Орскида яшәгән һәм эшләгән, аннан соң да биредә берничә тапкыр булган, Дәрдемәнд турында хезмәтләр язып, китаплар чыгарган язучы Л. Хәмидуллин шагыйрьнең Ырынбурдан китүендә башкарак сәбәпләр дә күрә. «Балалар язмышыннан кала приискалардагы хәл-әхвәлләр дә борчый Закир Рәмиевне. Бу буталчык заманда анда ни хәлләр икән? Прииск жиһазларын ватып, жимереп бетермәгәннәрме? Алтын бөртекләре сакланган таш келәтләр ышанычлы куллардамы? ... Орскига китешли шушы уйлар да борчыгандыр Дәрдмәндне. Шуңа күрә дә инде, гадәттәгечә юл төшүен көтмичә, Орскига кышын китәргә булганнардыр. Орск - приискалардагы хужалыкларны берләштереп торучы үзәк. Жай чыкса, аннан приискаларга да барып килергә мөмкин булачак. Бәлки шул тирәдә сугышып йөргән балаларның да хәлен белеп булыр. Рәмиевләр эш йөрткән Орск банкалары ни хәлдә икән?» [Хәмидуллин, 2009; б. 75-76]. Дәрдемәнднең Орскига китүенә болар да сәбәпче булырга мөмкин, чөнки зур хужалыкны, дала буйлап сибелгән дистәләгән алтын базларын, алтын сакланган келәтләрне алай гына ташлап калдырып булмый.

Төбәк тарихын өйрәнүчеләр язганча, Дәрдемәндләр гаиләсе Орскида төрле урыннарда - хатынының туганнарында да, арендалаган аерым йортта да яши, шәһәр өчен аклар һәм кызыллар арасында каты сугышлар барганда, авылларга, утарларына да китеп торалар. Гомумән, Дәрдемәнд гомеренең бу соңгы чоры тыныч булмый: шушы 3-4 елга революцияләр дә, гражданнар сугышы да, ачлыгы да туры килә, моның өстенә, буй житкән балаларының тифтән үлүләре дә килеп өстәлә.

Дәрдемәнд күңеленә тынычлык эзләп, гаиләсен ил өстенә килгән афәтләрдән саклап калу теләге белән Орскига кайтса да, ул иминлекне биредә дә таба алмый. Жәйгә таба биредә шәһәр өчен каты сугышлар башланып, ул айлар буе камалышта кала, әле аклар, әле кызыллар кулына күчә: бер ел эчендә дүрт тапкыр хакимият алышына. «В 1918-1919 годах, в период гражданской войны, город выдержал трёхмесячную осаду, затем четырежды захватывался воюющими сторонами» [Орск]. Дәрдемәнднең гаиләсенә дә кайгы артыннан кайгы килә. Балдызы Әсма Рәхмәтуллина-Ибраһимованың хатирәләреннән күренгәнчә, шагыйрьнең Морад исемле улын аклар мобилизовать итеп сугышка алалар, ә Жәгъфәрне - кызыллар. Бу сугышларда Морад тифтән үлә, Жәгъфәр бер кулсыз кала. 1919 елның көзендә олы уллары Искәндәрнең авырлы хатыны Шәрифзадә тифтән үлә, бер яшьлек оныклары Бәшир Дәрдемәндләр кулында кала. (Соңыннан бу ятим бала - Бәшир Рәмиев дөньякүләм танылган галим, СССРда беренче ЭВМ-комьютерларны уйлап табучы, техник фәннәр докторы, Дәүләт премиясе лауреаты исеменә ия була).

Үзе дә ул елларда Орскида яшәгән Әсма Рәхмәтуллина-Ибраһимованың

истәлекләреннән күренгәнчә, шәһәргә кызыллар керә башлагач, Ырынбур һәм Орск байлары акларга ияреп кача башлыйлар. Димәк, Ырынбурдан Орскига бер Дәрдемәнд гаиләсе генә түгел, башка байлар да кызыллардан качып килгән, кызыллар Орскига килеп житкәч, күпчелек татар байлары, акларга ияреп, бу шәһәрдән дә качкан. Ә Дәрдемәнд калган... «Илен яраткан, милләте белән калган» кебек олы төшенчәләрне бераз читкәрәк куеп, тормышның ачы чынбарлыгына да игътибар итик. Мондый шартларда, Дәрдемәнд кебек алтмышка житкән олы яшьтәге ир-ат, калган бөтен балалары hәм оныклары аңа карап торган зур гаилә башлыгы, нечкә күңелле шагыйрь, моңа кадәр жәмгыятьтә зур хөрмәткә һәм дәрәжәгә ия булган шәхес нишләргә тиеш иде соң? Балаларын, ятим оныкларын төяп, дутовчыларга һәм Колчак гаскәренә ияреп, урыс арбасына утырып, дөнья буйлап сукбайлыкка чыгып китәргәме? Анда аны һәм гаиләсен, нәселен нәрсә көтә?

Дәрдемәнд бу сорауларга нәкъ шул канлы, болганчык елларда язган шигыре белән үзе жавап бирә:

Куанды ил, канат какты мәләкләр,

Шашып, аң-таң булып шайтан төкерде!..

Житәр, жилкенмә, йолкынма, күңел, син,

Кияү булсаң да, ул туйга түгел син!

Жиһан тормыш туен иткән чагында,

Синең урның - үлекләр аймагында [Дәрдмәнд, 2003; 219 б.].

Дәрдемәнд турындагы гыйльмияттә шагыйрьнең бу чор ижатыннан берничә шигыре генә билгеле. Ә. РәхмәтуллинаИбраһимова шагыйрьнең басылмыйча калган язмаларын Жәгъфәр хатынының вокзалда чемоданы белән бергә урлатуын яза. Күңеле төшенке, тормышы кайгылы, киләчәге шомлы булса да, Дәрдемәнд шушы шартларда да 
жәмгыятьтә үз урынын табарга омтылып карый. Л. Хәмидуллин мәгълүматларына караганда, бу вакытта ул Казанда булып китә: «Орскида яшәү дәверендә бер мәртәбә Казанда булганлыгы да мәгълүм. 1919 елның гыйнварында татар язуын камилләштерүгә багышланган конференция оештырыла. Унынчы елларда ук имля алыштыруга карата үз фикерен матбугатта белдергән Дәрдмәнд тә аңа чакырылган була» [Дәрдмәнд, 2003; 217 б.].

Бу елларда Орск шәһәре туктаусыз сугышлардан, тифтән, соңрак инде ачлыктан газап чиксә дә, тормыш барыбер дәвам итә. 1918 елның башында ук биредә мөселман Шурасы төзелә, 1919 елны икенче мөселман китапханәсе ачыла, татар клубы эшли башлый, әлеге вакыйгаларда Дәрдемәнднең дә катнашы булган, дип уйлыйсы килә. Шәһәрне кызыллар алгач, большевиклар татарларны, милли зыялыларны төрле оештыру эшләренә тарталар, аларның кайберләрен жаваплы урыннарга да сайлап куялар. «На I Орском уездном съезде Советов 28 июня 1918 г. был избран Уисполком, в состав которого вошли татары Мусин Мухаметсафа Сафич, Даутов Абдулла Мухаметзянович, секретарем был избран башкирин Татлыбаев Зариф. Проводилась работа среди женщин-мусульманок: первое общее собрание с ними было проведено 27 сентября 1919 г. Организатором среди женщин-татарок была избрана Забирова Фатима. Продовольственный отдел города с октября 1919 г. возглавлял А. М. Даутов При Орском РКП (б) в 1920 г. была создана мусульманская секция, потом подотдел нацмен, просуществовавший до 1927 г. Первым председателем ее избран Амиров» [Черкас, 2010, с. 196].

Болар арасында Дәрдемәнд юк. Рухы белән дә, тәрбиясе белән дә бөтенләй башка халәттә булган Дәрдемәнд большевик татарлар арасына барып керә алмый. Алай да, аның нацменнар комиссары Абдулла Дәүләтшин белән аралашканлыгы билгеле, чөнки бу егет Орскида «Шәрыкъ клубы» бинасында татарча газета чыгара башлый.

«Дәрдмәнд ара-тирә шул бинага килеп, төбәктәге милли азчылык арасында эшләргә тиешле яшь комиссар Абдулла Дәүләтшин белән дә аралашкалый, - дип яза Л. Хәмидуллин. - Дәүләтшин Орскида 1920 елдан беренче милли газета - „Ирек йолдызы“н чыгара башлый. Атна саен нәшер ителгән ике битле бу газетада әдәбият-сәнгать почмагы: шигырь, әдәби парча, мәдәният яңалыклары урнаштырыла. Комиссар бүлмәсендә үзәктән алынган газеталар белән дә танышып була» [Дәрдмәнд, 2003: 218 б.].

Тарихи чыганаклардан күренгәнчә, «Ирек йолдызы» газетасы Орск шәһәрендә 1919-1921 елларда чыга, аның берничә саны гына кайбер китапханәләрдә сакланып калган: Казанда Татарстан Республикасының Тарихи-сәяси документлар үзәк дәүләт архивында - 1921 елның 12нче саны; Мәскәүдә Россия Федерациясенең Дәүләт китапханәсендә - 1921 елның 11нче саны; Петербургта Россия Федерациясенең Милли китапханәсендә - 1921 елның 11нче саны [Гайнанов, Мәрданов, Шәкүров, 1999; б. 71-72]. Л. Хәмидуллин «Ирек йолдызы» газетасының бер саны Орск музеенда саклануын хәбәр итә. Әлеге матбугат битләрендә Дәрдемәнд турында хәбәр, я булмаса шигырьләренең басылып чыгуы хакында, кызганычка каршы, мәгълүматлар юк. Димәк, киләчәктә бу юнәлештә дә эзләнүләрне активлаштырасы бар.

Шулай итеп, Дәрдемәнд Орскида өч елдан артык яши, тормыш алып барырга ярдәмгә улы Искәндәр дә кайта, чит илләрдә укыган бу әзерлекле белгеч советлар өчен дә бик кирәкле кеше була, аңа алтын табу приискаларына эш тәкъдим ителә. (Әмма соңыннан аны «халык дошманы» дип кулга алалар һәм ул сөргендә үлә). Бәлки шушы чордадыр, Рәмиевләр үзләренең бөтен алтын запасларын (ә алар тонналап була) советларга тапшыралар; тарихчылар «үз теләкләре белән» дигән фикердә тора. Минем карашымча, анда теләкне сорап тормаганнар, күпчелек байларны, йортларыннан өстерәп чыгарып, терәп атканны, алтынны тартып алалар да алалар. Дәрдемәнд яңадан Ырынбурга кайтырга ашыкмый, югыйсә, 1920-1925 елларда биредә казах автономиясенең башкаласы була, казахлар исә байларга алай ук каныкмыйлар. Бу вакытта әле Рәмиевләрнең Ырынбурдагы йорт-жирләренә дә кагылучы булмый. Гомеренең соңгы елларында Дәрдемәнд Орскида кала, биредә яши, биредә үлә, биредә күмелә... Димәк, тәкъдирендә шулай язылган була...

Л. Хәмидуллин Дәрдемәнднең ачлык вакытында халыкка ярдәм итүе турында хәбәрләр ишетүен дә әйтә: «Мәсәлән, 1960-70 елларда Орск шәһәрендә очрашулар вакытында берничә кеше, шул исәптән 1920 елларда шунда „Кулланучылар жәмгыяте“ндә эшләгән Габдулла Дәүләтшин дигән бер ветеран-коммунист Дәрдмәнднең 1921 елда шушы төбәктә ачлыкка 
каршы чаралар күрү комиссиясендәме, хәйрия оешмасындамы $\mathrm{Y}^{3}$ теләге белән эшләвен сөйләделәр. Мондый хәбәрне раслардай рәсми документ әле табылмаган» [Бертуган Рәмиевләр, 2002; 36 б.]. Бу факт дөреслеккә туры килергә дә мөмкин, чөнки Дәрдемәнд халыкның фажигасенә читтән карап тора торган шәхес түгел, аягында йөргәндә, сүзе үткәндә, ул ачлык афәтенә каршы да көрәшеп карагандыр, әмма адәм баласы гына жиңәрлек фажига булмаган шул ул... Ачлык Орскины да кырып сала, кешеләр берәмләп түгел, меңәрләп үләләр. «Новым испытанием стал голод 19211922 годов. В 1920 г. население города составляло более 16 тысяч человек, а к 1923 году оно сократилось до десяти с половиной тысяч» [Орск. Фотоальбом. С. 22.]. Һәм шушы меңнәр арасында милләтнең бердәнбере, татар шагыйре Дәрдемәнд - алтынчы Закир Рәмиев тә була...

Дәрдемәнднең үлем сәбәпләренә һәм вакытына карата төрле фикерләр яши. Рәсми чыганаклардан күренгәнчә, 1921 елның көзендә шагыйрь Ырынбурга авыру кызының хәлен белергә бара. Аны күмеп, Орскига кайтканда, юлда бик туңа һәм тиз арада үлә. «Олы кайгы кичеру, озын юлның мәшәкате, көзге суык аны тәмам хәлсез итәләр, - дип яза Л. Хәмидуллин. - Кайтып, бер атна чамасы авырып яткач, 1921 елның 9 октябрендә Закир Рәмиев-Дәрдмәнд вафат була. Шәһәр янәшәсендәге Ильяс авылы зиратына жирләнә» [Дәрдмәнд, 2003; 218 б.].

Чыганактагы фактлар барысы да диярлек дөрес, әмма «бер атна чамасы авырып яткач» дигән сүзләр күнелдә шик уята. Шикләнү өчен сәбәп тә бар, чөнки Дәрдемәнднең балдызы Ә. Рәхмәтуллина-Ибраһимова Гөлсемнең, ягъни, шагыйрьнең олы кызы Өммегөлсемнең Ырынбурда яз көне үлүен хәбәр итә: «Оренбургта Гөлсем апалар ачыгып кыш чыгалар, яз житкәч, Гариф езни базардан, белмим, бозлы карбызмы алып кайта. Гөлсем апа ач килеш ашый, эче үтеп, холера микән, үлеп китә» [Рәмиевләр, 1999; 185 б.].

Бу хатирәдә безнең өчен Өммегөлсемнең Ырынбурда яз көне үлүе хакында мөһим яңа факт бар: Дәрдемәнд анда яз көне барган булып чыга. Ә. Рәхмәтуллина-Ибраһимовага ышанмаска безнең хакыбыз юк, чөнки аңа бу вакытта 16 яшь булып, ул барысын да яхшы хәтерли. Шулай ук Өммегөлсемнәрнең Ырынбурда ачлы-туклы яшәгәннәре ачыклана. Дәрдемәнд, аларга үз авызыннан өзеп бераз булса да, азык илтә бара. Истәлекләрдә Орскида Дәрдемәнд- ләрнең боткага калулары хакында да языла, ягъни, элеккеге мул тормыш та юк, хезмәтчеләр дә юк, ашарга да үзләре пешергән боткадан кала берни юк. Әлбәттә, ботка булу ул әле ачлык түгел, әмма өйдә барлык ризык запасларының беткәнлеген күрсәтә.

Шулай итеп, Дәрдемәнд Ырынбурга олы кызы янына 1921 елның язында барып, аннан ятим оныкларын алып, юлда авырып кайткан булса, ул әле үлеменә кадәр ярты ел буе урын өстендә яткан, дигән сүз. 3. Рәмиев авырып ятканда, аның янына Р. Фәхреддиннең килеп киткәнлеге билгеле. Бу очрашуның, бигрәк тә Уфада яшәүче Риза хәзрәт өчен бер атна эчендә булуы мөмкин түгел. Дәрдемәнд белән соңгы очрашуы турында Р.Фәхреддин болай дип яза: “Оренбургдан Уфага сәфәремдә янына кереп видаг иттем (саубуллаштым. - Ф. Б.). Авыру вә түшәк өстендә иде. "Хәлем яхшыланадыр" дигәненә һәм дә үзенең беркадәр сөйләшәсе килүне белүемә күрә, янында беркадәр утырдым. Шул вакыт: “Хәзрәт! Бу көнге хәлләр беркадәр төзәлсә, без “Вакыт” берлә “Шура”ны тәкрар чыгарырмыз, шул вакытта Оренбургка кайтып, әүвәлге хезмәтләреңездә дәвам итүеңезне өмидләнәмез вә үтенәмез, сезнең берлә берлектә Хижаз (Хаж кылу күздә тотыла. - Ф. Б.) сәфәренә бару фикеремдә камил, моны үзеңез берлә сөйләшкән дә идек”, - диде. "Аллаһ нәсыйб итсә, безнең тарафымыздан эш калмас", - дип видаг кылып чыгып киттем. Ахыргы күрешүем шушы булды [Фәхреддин, 2010; 354 б.)].

Бу очрашу кайчан, кайда булган - безгә төгәл билгеле түгел, әмма мантыйк буенча, бу Дәрдемәнд үлем түшәгендә ятканда булган хәл, дип фаразларга була. Билгеле булганча, 1918 елның февраль азагында Ырынбурдан берсе Уфага, берсе - Орскига киткәндә, шагыйрь үлем түшәгендә ятмый, аннан соң да әле өч елдан артык яши. Димәк, бу соңгы очрашу 1921 елда булган, әмма аe һәм көне билгесез. Бу ике бөек шәхеснең, милләтнең ике газиз улының соңгы очрашуы, бәхилләшүе булган. Дәрдемәнд гомеренең сонгы мизгелләрендә дә милли матбага турында кайгырткан, «Вакыт» газетасы белән «Шура» журналын яңадан чыгару турында хыялланган. Ризаэддин хәзрәт белән берлектә Хаж кылырга ниятләгән, әңгәмәдән күренгәнчә, бу турыда алар элегрәк тә сөйләшкән булалар. Димәк, моңа хәтле Дәрдемәнд тә, Ризаэддин Фәхреддин хәзрәтләре дә Хаж кылмаган булалар? Һәрхәлдә, андый мәгълүмат табылмады. 
Л. Хәмидуллинның «Дәрдмәнд олы кызы янына Ырынбурга көзен барган» дигән сүзләрен раслый торган башка дәлил бар. 3. Рәмиевне бик якыннан белгән, «Вакыт» газетасында баш мөхәррир булып эшләгән Фатыйх Кәрими 1927 елда аның үлеме турында болай дип яза: «1921 елның октябрь аенда Оренбургтан кайткан вакытта тимер юлда суык тигереп, 9 октябрьдә Орски шәһәрендә вафат булган һәм шунда дәфен ителгән. Үлгәндә яше 62 дә булган» [Кәрими, 1928; 17 б.].

Зәки Вәлидинең дә Орскига авыру Дәрдемәнднең хәлен белергә килүе мәгълүм: ул шулай ук шагыйрьнең үзе турында түгел, ә милләте хакында кайгыртуына игътибар биргән. 3. Вәлидинең Дәрдемәнд белән соңгы очрашуының кайчан, кайсы айда булуын белү мәсьәләгә бераз ачыклык кертер иде.

Татар шагыйре Дәрдемәнд вафатының төп сәбәбе аеруча зур сораулар уята: ул ачтан үлгәнме, әллә тифтәнме? Гадәттә, бу ике афәт, бер-берсенә тагылып, янәшә йөриләр. Ә. Рәхмәтулллина-Ибраһимова истәлекләреннән күренгәнчә, Орскида бу нәселдә ачтан үлүчеләр булмаган, булса - язар иде. Аның үзенең 18 яшьлек Сара апасы 1921 елда тифтән үлә: «Езни күмәргә акчалар әниемә бирә, өч куй да китерә». «Үлем хәсрәтеннән айный алмый торганда тагын да хәсрәт килә: езни иң олы кызы Гөлсем апаның хәлен белергә, азыклар илтергә Оренбургка бара» [Рәмиевләр, 1999; 185 б.], - дип дәвам итә Әсма РәхмәтуллинаИбраһимова.

Дәрдемәнднең Ырынбурга азыклар илтү факты гаиләнең бу вакытта әле ачлык газапларына дучар ителмәве хакында сөйли. Әмма ачлык бу нәселгә көзен ишек шакырга мөмкин. Өммегөлсемнең вафат булу көнен ачыклау бу сорауга бераз төгәллек кертер иде. «Аннан кайткан вакытта поездлар ягылмаган булганга езни бик өшеп кайта, - дип яза хатирәләр авторы. - Бронхит белән авырып, терелә алмый үлеп китә. Врач, йөрәге бик начар, ди...» [Рәмиевләр, 1999; 185 б.]. Әйе, йөрәк авыруы да булырга, бронхиттан үпкә чиренә әйләнергә дә мөмкин. Тиф белән ачлык та Үз корбаннарын чүпләп торган.

Шагыйранә тәхәллүсе-псевдонимы сагышлы-моңлы булган Дәрдемәнд, гүя алда тагы да шомлырак, куркынычрак заманнар киләсен сизенеп, бу гаделсез дөньяны ташлап китә. Үз жирендә, Үз гаиләсендә, иң якыннары арасында тынычлап жан бирә, мөселманча женаза намазы укылып, жиргә тапшырыла.
Дөрес, ул күмелгән татар зираты өстенә сугыш елларында хәрби завод китереп салалар, аның кабере өстендә ракеталар житештерә башлыйлар, әмма шагыйрь жаны инде күптән бу тар каберне ташлап, Аллаһ хозурына очкан була... Татар халкының затлы шагыйре Дәрдемәнднең милләткә, мәңгелек васыяте булып, үләр алдыннан язган шигырь юллары кала: «Кала торган нәрсә - биредә туган һәм яши торган кешеләр, алар ата-бабаларының дан шөһрәтләрен истә тоталар, шуларны буыннанбуынга тапшырып киләләр. Бу шигырендә Дәрдемәнд үзе һәм „халкына“ булган мөнәсәбәте турында сөйли» [Фридерих, 2014; 99 б.].

\begin{tabular}{|l|l|}
\hline Гөрләгән сулар & Ни газизрәк - бу \\
башында, & ватанмы? \\
Тыңлагыз, шунда үтәр - & Аһ, туган каүмем \\
Йөрсә сыктап таң- & газиз! \\
сәхәрләр & Ул мөкаддәс кан белән \\
Моң-сагышлардан & ул \\
хыял. & Изге сөткә ни житәр!.. \\
И туган илнең hавасы, & Сөт калыр, ватан \\
Рәнжемим, зинһар & китәр! \\
күтәр! & Сөт калыр, ватан \\
Рәнжемим, зинһар & китәр! \\
күтәр! & [Дәрдмәнд, 2003; 61 б.] \\
\hline
\end{tabular}

Димәк, татар халкының ижтимагый-рухи күтәрелешенә, милли сүз сәнгатенең яңарышына зур өлеш керткән олы фикер иясе, абруйлы жәмәгать эшлеклесе Дәрдемәнднең фәнни биографиясендә Орск төбәге мәгълүм урын алып тора. Бу шәһәрдә шагыйрь тормышына һәм язмышына сизелерлек йогынты ясаган вакыйгалар була. Ул, биредә шәхес буларак формалашып, үсеш кичерә, гаилә корып жибәрә, Россиянең алтын санагатендә эре алтынчы булып житешә, милләтпәрвәр, милләт хадиме төсендә үзен реальләштерә. Алга таба төбәкнең мәдәни һәм сәяси тормышында актив катнашып, татар милләтенең алгарыш һәм үсеш кыйбласын билгели. 1917 елдан соң дөньялар үзгәреп китеп, авыр һәм болгавыр заманнар башлангач, Орск аңа, гаиләсенә сыену почмагы була. Дәрдемәнднең фани дөньяда соңгы сәгатьләре биредә үтеп, ул мәңгелеккә - теге дөньяга күчә. 


\section{Әдәбият ${ }^{2}$}

Әбелгазый Баһадир хан. Шәжәрәи төрек. Казан: Татар.кит.нәшр., 2007. 134 б.

Батталов $Г$. A. Казан төркиләре. Тарихи язмалар / тәрж. А. Рәхимова; нәшр. ред. Л Хәмидуллин. Казан: Татар. кит. нәшр., 1996. 192 б.

Бертуган Рәмиевләр: Фәнни-биографик жыентык. Казан: Рухият, 2002. 368 б.

Валетдинов Р. Татары в Орске // Орск татарлары. 2010. Май. № 5.

Гайнанов Р. Р., Мәрданов Р. Ф., Шәкүров Ф. Н. Татар вакытлы матбугаты (1905-1924). Казан, 1999.

Гыйлажсев T. Ш. Мирхәйдәр Фәйзи драматургиясе // Фәйзи М. М. Пьесалар / төз., кереш мәкалә һәм иск. авт. Т. Ш. Гыйлажев. Казан: Татар. кит. нәшр., 2017. Б. 5-48.

Даутов Р. Н., Нуруллина Н. Б. Дәрдемәнд // Совет Татарстаны язучылары: Биобиблиографик белешмә. Казан: Татар. кит. нәшр., 1986. Б. 165-166.

Дәрдмәнд / кереш сүз авт. Л. Хәмидуллин; төз., фоторәсемнәр һәм макет авт. 3. Бәширов. Казан: Татар. кит. нәшр., 2003. 239 б.

Дәрдмәнд. Исә жилләр: Шигырьләр. Истәлекпарчалар. Вак хикәяләр / төз. һәм иск. язучы Р. Даутов. Казан: Татар. кит. нәшр, 1980. 254 б.

Заһидуллина Д. Ф. Дөнья сурәте үзгәрү: ХХ йөз башы татар әдәбиятында фәлсәфи әсәрләр: Монография. Казан: Мәгариф, 2006. 1916.

Искәндәр һәм Бәшир Рәмиевләр / төз. М. Рәхимкулова. Оренбург: Яңа вакыт, 1995.

Кәримев Ф. Дәрдмәнд (1859-1921) // Дәрдмәнд әсәрләре / Төз. И. Рәми. Казан: Яңалиф, 1928. Б. 818.

Рәмиевләр / төз. М. Рәхимкулова. Ырынбур: Яңа Вакыт, 1995. 96 б.

Рәмиевләр / төз. һәм нәшир М. Рәхимкулова. Оренбург: Яңа Вакыт, 1999.

Халит Г. Дәрдемәнд // Татар әдәбияты тарихы. Алты томда: XX гасыр башы. Казан: Татар. кит. нәшр., 1986. Б. 194-214.

Хисамов Н. Дәрдемәнд: тормышы һәм ижаты турында очерк // Казан утлары. 1989. 312. Б. 165175.

Хәмидуллин Л. Кичке шәфәкъ: документаль повесть, эссе, очерклар. Казан: Татар. кит. нәшр., 2009. 255 б.

Гилазов Т. Ш. Поэзия Дердеменда в контексте Запада и Востока // Вестник ЧелГУ. Филология. Искусствоведение. 2014. № 10 (399). С. 46-51.

Фридерих $M$. Дөнья әдәбияты контекстында Дәрдемәнд ижаты // TATARICA. 2014. № 2 (3). C. 85-105.

Фәхреддин Р. Aсар. Беренче том. Казан: Рухият, 2006. 359 б.

\footnotetext{
2 «Әдәбият» исемлегендә күрсәтелгән хезмәтләрдән тыш шулай ук Орск шәһәрендә 2009-2013 елларда басылып чыккан «Орск татарлары» бюллетене язмалары, интернетта бу төбәк тарихы белән бәйле мәкаләләр файдаланылды.
}

Фәхреддин Р. Асар. Икенче том. Казан: Рухият, 2009. 303 б.

Фахреддин P. Асар. Өченче һәм дүртенче томнар. Казан: Рухият, 2010. 646 б.

Игнатьев Р. П. Древние здания в Троцком уезде Оренбургской губернии // Оренбургские губернские ведомости. 1868. № 21.

Искандаров Р. Ш. Оренбургские татары: историко-энциклопедический очерк. Казань: Татар. кн. изд-во, 2009. 271 с.

Оренбургская губерния. Список населенных мест по сведениям 1866 года / сост. и изд. Центр. стат. ком. М-ва внутр. дел; обраб. В. Зверинским. С.Пб: Изд-во Центр. стат. ком. Мин. внутр. дел, 1871, 108 с.

Оренбургский листок. Оренбург 1887. 18 сентября.

Орск // Википедия. 2019-2019. URL: https://ru.wikipedia.org/?oldid=103782319 (дата обращения: 05.09.2019).

Орск: Фотоальбом / Лит. текст: В.Лаврик; Фото, ил.: В. Тихомиров, В. Щербаков; Под. общ. ред. В. Щербакова. Москва, 1995. 107 с.; ил.; 24 см.

Попов С. А. Рукопись. ОИКМ, инв. № 29/115a.

Попов $C$. A. Тайны пятимаров: очерки по древней и средневековой истории Оренбургских степей / ред. Н. Т. Струздюмов, Е. В. Новский. 2-е изд., испр. и доп. Челябинск: Юж.-Урал. кн. изд-во, 1982. 246 с.

Ризаэтдин бин Фәхретдин. Оренбург, 1998. 250 б.

Рычков П. И. История Оренбургская. Уфа: ЦЭИ УНЦ РАН, 2001. $201 \mathrm{c}$.

Рычков П. И. Топография Оренбургской губернии / коммент. И. В. Кучумова, Ф. А. Шакуровой. Уфа, 1999. 439 с.

Саяпова А. М. Поэзия Дардменда и символизм. Казань: Казанский пед. ун-т, 1997. 210 с.

Саяпова A. M. Дэрдеменд и философия экзистенциализма // TATARICA. 2014. № 2 (3). C. 68-84.

Смирнов К. Ф. Сарматы на Илеке Сарматы на Илеке. Москва: Наука, 1975. 176 с.

Соболевская О. В. Биография // Литертаурная энциклопедия терминов и понятий / гл. ред. и сост. А. Н. Николюкин. Москва НПК «Интелвак», 2003. C. 90-91.

Татары в Оренбургском крае. Оренбург: изд-во «Димур», 1997. 228 с.

Хабутдинова М. М. Клад Дэрдменда // Идел. 2005. № 9. С. 57-59.

Хабутдинова М. М. Творчество Дэрдменда в аспекте диалога культур (на примере анализа стихотворения «Кораб» («Корабль») (1908)) // Диалог культур: русско-татарские взаимосвязи // Материалы историко-филологического семинара Всероссийской научно-практической конференции «Славянская культура: истоки, традиции, взаимодействие» 7 Кирилло-Мефодиевских чтений. Выпуск 2. МоскваЯрославль: Ремдер, 2006. С. 86-92. 
Черкас Т. Г. Хронограф города. Орск: Орский историко-краеведческий музей, 2005. 67 с.

Черкас Т. Г. Мусульмане Орска в XIX - начале XX века // Орские известия (вкладыш «Туган тел»). 2003. 28 января.
Черкас Т. Г. Орск: от крепости до города: монография / Т.Г. Черкас. Орск: ОГТИ, 2010. 263 с.

Шакуров Ф. Развитие исторических знаний у татар до февраля 1917 года. Казань: изд-во Казан. ун-та, 2002. 128 с.

\title{
ВЕЛИКИЙ ДЭРДМЕНД: НОВЫЕ ФАКТЫ ПО ОРСКОМУ ПЕРИОДУ ЖИЗНИ ПОЭТА (К 160-ЛЕТИЮ СО ДНЯ РОЖДЕНИЯ)
}

\author{
Фаузия Авхадиевна Байрамова, \\ Союз писателей Республики Татарстана, \\ Россия, 420015, г. Казань, ул. Муштари, д. 14, \\ ittifak@yandex.ru.
}

\begin{abstract}
Объектом изучения выступает Орский период жизни известного татарского поэта, национального деятеля, золотопромышленника Дэрдменда (Закира Рамиева). Научная биография писателя основательно изучена Ф. Карими, Р. Фахретдином, М. Гайнуллиным, М. Рахимкуловой, Л. Хамидуллиным, краеведом из г. Орска Т. Г. Черкас. В статье вводятся в оборот новые факты, рассматриваются в новом ракурсе ранее изученные проблемы. В этом городе прошли детство и юность 3. Рамиева. В работе выявлена роль Орска в формировании личности писателя. Доказано, что социальная и культурная жизнь города оказала благотворное влияние на формирование его как писателя, золотопромышленника, общественного деятеля, известного как в татарском мире, так и в России. Раскрыты обстоятельства жизни писателя после Октябрьской революции 1917 г., связь с г. Орском в последние годы жизни.
\end{abstract}

Ключевые слова: татарская поэзия, поэт, золотопромышленник, биография, г. Орск, Дэрдменд. 